\title{
Comparison of Hemoglobin Correction Effects According to Storage Period and Other Factors in the Transfusion of Packed Red Blood Cells in Neonatal Intensive Care Unit Patients
}

\author{
Ji Hyun Park, Seom Gim Kong, and Yoo Rha Hong \\ Department of Pediatrics, Kosin University College of Medicine, Busan, Korea
}

\section{ABSTRACT}

Purpose: Preterm infants frequently require red blood cell (RBC) transfusions in neonatal intensive care units (NICU). Storage RBCs undergo many changes during storage periods. We aimed to compare the hemoglobin $(\mathrm{Hb})$ correction effect according to the period of $\mathrm{RBC}$ storage and investigate the factors influencing $\mathrm{Hb}$ correction.

Methods: This retrospective study reviewed the medical records of 289 patients who received RBC transfusion more than once in the NICU of Kosin University Gospel Hospital between February 2006 and March 2016. The subjects were classified into two storage groups: short-term ( $\leq 7$ days, $n=88$ ) and long-term ( $>7$ days, $n=201$ ), according to the period of RBC storage. We checked Hb levels by complete blood cell count tests conducted within 2 days before and 5 to 9 days after the first transfusion. We compared the $\mathrm{Hb}$ difference between the two groups and analyzed the factors influencing $\mathrm{Hb}$ correction.

Results: Excluding the use of an invasive ventilator, there was no significant difference between the two groups in terms of clinical characteristics. There was no significant difference in the $\mathrm{Hb}$ correction effect between the two groups $(P=0.537)$. Birth weight greater than $1,500 \mathrm{~g}$, higher weight at transfusion, and larger volume of transfusion were significant prognostic factors affecting greater changes in $\mathrm{Hb}$. In addition, surgery experience, higher $\mathrm{Hb}$ level at transfusion, and additional blood tests were found to be significantly associated with less changes in $\mathrm{Hb}$.

Conclusion: The RBC storage period did not affect the $\mathrm{Hb}$ correction effect. The $\mathrm{Hb}$ correction effect may be diminished in infants with lower birth weight and lower weight at transfusion under unstable clinical conditions.

Key Words: Premature birth, Erythrocyte aging, Erythrocyte transfusion, Newborn infant, Hemoglobins
Received: 17 September 2018

Revised: 22 October 2018

Accepted: 7 November 2018

Correspondence to: Yoo Rha Hong

Department of Pediatrics, Kosin University Gospel Hospital, Kosin University College of Medicine, 262 Gamcheon-ro, Seo-gu, Busan 49267, Korea Tel: $+82-51-990-6278$

Fax: +82-51-990-3338

E-mail: pondhong@gmail.com

We submitted this abstract on poster session at The 2nd Korea-Japan-Taiwan joint congress on neonatology 2018.

Copyright(c)

By Korean Society of Neonatology.

All right reserved.

This is an Open-Access article distributed under the terms of the Creative Commons Attribution Non-Commercial License (http://creativecommons.org/licenses/ by-nc/4.0), which permits unrestricted non-commercial use, distribution, and reproduction in any medium, provided the original work is properly cited. 
서론

수혈은 신생아중환자실에 입 원한 미숙아에게 흔히 시행 되며 1회 수혈로 빈혈이 교정되지 않아 추가 수혈이 필요한 경우가 많다 ${ }^{1,2)}$. 특히 극소 저체중 출생아들(very low birth weight infants, VLBWI) 은 더 많은 횟수의 적혈구 수혈을 받게 되며 최근 VLBWI의 생존율 이 증가함에 따라 적혈구 수혈 빈도도 증가하고 있다 ${ }^{3-5)}$. 적혈구 수 혈 횟수가 증가함에 따라 감염성 질환의 전파 및 동종면역반응을 유 발하는 공여자 항원에 노출 위험도 증가하게 된다 ${ }^{6,7)}$.

이에 대한 대안으로 분할적혈구(red blood cell aliquot)를 수혈하 는 방법이 시행 되고 있다. . 이는 한 단위의 혈액을 적은 양으로 나누 어 보관하였다가 필요할 때 같은 공여자의 혈액을 여러 번 사용하는 방법으로 아직 국내에서는 보편화되지 않았다. 분할적혈구를 사용 하게 되면 폐기되는 혈액과 공여자 노출 기회를 줄일 수 있다는 장점 이 있으나 적혈구 저장 기간이 길어지게 되는 단점이 있다.

적혈구 제제는 항응고보존제로 citrate phosphate dextrose adenine-1 (CPDA-1)을 사용하는 경우 채혈 후 35일까지 사용 가능 한데 저장 기간 동안 적혈구는 많은 변화 과정을 거친다 ${ }^{8,9)}$. 적혈구 용혈에 따른 유리 혈색소(free hemoglobin) 증가, 적혈구 모양의 변 성과 손상, 대사 변화 등 저장 기간이 길수록 적혈구 불안정성이 증 가한다고 알려져 있다 ${ }^{10-12)}$. 이로 인해 저장 기간이 긴 혈액 제제를 수 혈할 경우 저장 기간이 짧은 혈액에 비해 수혈 효과는 감소하고 수혈 로 인한 부작용이 증가할 수 있다는 추측이 있었다 ${ }^{6,13,14)}$. 그러나 대 량 수혈의 경우와는 달리 신생아의 1 회 수혈 양은 적고 주입 속도가 느리기 때문에 저장 기간에 따른 영향이 미미하다고 알려져 있다. 그럼에도 불구하고 저장 기간에 따른 적혈구 변성의 이론적인 사실 에 근거하여 신생아를 담당하는 의사들은 좀 더 신선한 적혈구 제제 를 선호하는 경향이 있다 ${ }^{15}$. 이에 저자들은 신생아중환자실에 입원 한 환자를 대상으로 적혈구 혈액 제제의 저장 기간이 혈색소 교정 효 과에 영향을 주는지와 그 외 혈색소 교정 효과에 영향을 주는 인자들 을 알아보고자 하였다.

\section{대상 및 방법}

본 연구는 후향적 의무기록을 통해 시행 된 연구로 2006년 2월부 터 2016년 3월까지 고신대학교 복음병원 신생아중환자실에 입원 하여 적혈구 수혈을 1 회 이상 받은 환자를 대상으로 하였고 고신 대학교 복음병원 기관생명윤리위원회의 승인을 받아 시행되었다 (KUGH 2017-11-020-004). 생후 첫 수혈로 제한하여 분석하였고 의 무기록을 토대로 수혈 날짜를 확인하였다. 수혈 처방전에 표기된 혈 액의 고유 번호를 확인하여 대한적십자사의 혈액정보공유시스템을 통해 혈액의 채혈 날짜를 확인하였다 ${ }^{16)}$. 혈액 제제의 채혈일과 수혈
일의 차이를 적혈구 저장 기간으로 정의하였다. 7 일 이내 저장 기간 의 적혈구 제제를 수혈받은 단기 저장군과 7일 초과 저장 기간의 적 혈구 제제를 수혈받은 장기 저장군으로 분류하였다.

연구 기간 동안 1,748 명의 환자가 본원 신생아중환자실에서 치료 받았다. 대한신생아학회에서 발간한 신생아 진료지침의 표준 수혈 기준에 따라 수혈을 시행하였다(Appendix) ${ }^{17)}$. 적혈구 제제 수혈을 결정할 때 저장 기간에 대한 제한을 두지 않았고 분할적혈구를 사용 하지 않았다. 방사선 조사된 적혈구 제제를 백혈구 여과제거필터를 이용하여 주입할 용량 $(10-15 \mathrm{cc} / \mathrm{kg})$ 만큼 주사기로 뽑은 후 주입 펌 프(syringe pump)를 사용하여 3-4시간에 걸쳐 수혈하였다. 입원 환 자 중 1 회 이상 수혈받은 환자는 총 315 명이었다. 이 중 수혈 후 5-9 일 이내 전체혈구계산(complete blood cell count, $\mathrm{CBC}$ ) 검사를 하 지 않았던 26명을 제외한 289 명이 최종 분석 대상이 되었다. 단기 저 장군은 88 명, 장기 저장군은 201명이었다.

두 군 간의 임상적 특징을 비교하기 위해 재태 연령, 출생체중, 분만방법, 성별, 다태아 유무, 쌍생아 간 수혈증후군(twin-to-twin transfusion syndrome), 아프가 점수와 입원 기간 중 총 수혈 횟수를 조사하였다. 수혈 후 혈색소 교정 효과에 영향을 줄 수 있는 요인으 로 입원 시 혈색소 수치, 수혈 당시의 나이 (postnatal days), 체중, 수 혈 양, 장관 영양의 양, 정맥 영양 시행 여부, 침습적 인공호흡기 사 용 여부, 수혈 당시 C-반응성 단백(C-reactive protein) 수치를 조사하 였다. 또한 수혈 전후 2 주 이내에 동반된 질환으로 뇌실내출혈, 급성 골수성백혈병, 일과성 골수형성이상증후군, 용혈 빈혈 등의 혈액 질 환, 괴사성 장염, 소화기 출혈, 균이 동정된 패혈증과 균이 동정 되지 는 않았으나 임상적으로 패혈증을 의심했던 경우와 수술 여부를 조 사하였다.

두 군 간의 혈색소 교정 차이를 비교하기 위해 $\mathrm{CBC}$ 검사로 확인했 던 수혈 전 2일 이내 혈색소 수치와 수혈 후 5-9일 이내 혈색소 수치 를 조사하였다. 이 둘의 차이를 수혈로 인한 혈색소의 교정 효과로 정의하였다. 두 번의 $\mathrm{CBC}$ 검사 시기 사이에 환자의 불안정한 상황 때문에 시행 되었던 $1 \mathrm{cc}$ 이상 채혈한 횟수와 추가 수혈한 횟수를 비 교하였다.

두 군 간의 차이를 확인하기 위해 범주형 변수에 대해서는 chisquare 검정 또는 Fisher's exact 검정을, 연속형 변수에 대해서는 independent 검정 또는 Mann-Whitney's $U$ 검정을 사용하였다. 정 규성 검정을 위해 Shapiro-Wilk's 검정을 실시하였다. 수혈 후 5-9 일 이내의 혈색소 수치 변화와 독립적으로 관련된 예후인자를 확인 하기 위해 선형회귀분석을 사용하여 일변량 및 다변량 분석을 수행 하였다. 모든 변수는 다중선형회귀분석에서 공변량으로 간주되었 고 유의한 차이를 보인 변수를 포함하여 stepwise variable selection method를 사용하여 multivariate model을 수행하였다. 모든 통계분 석은 SPSS version 24.0 (IBM Co., Armonk, NY, USA)을 사용하여 수 행되었으며 $P$-value가 0.05 미만인 경우 통계적으로 유의한 것으로 


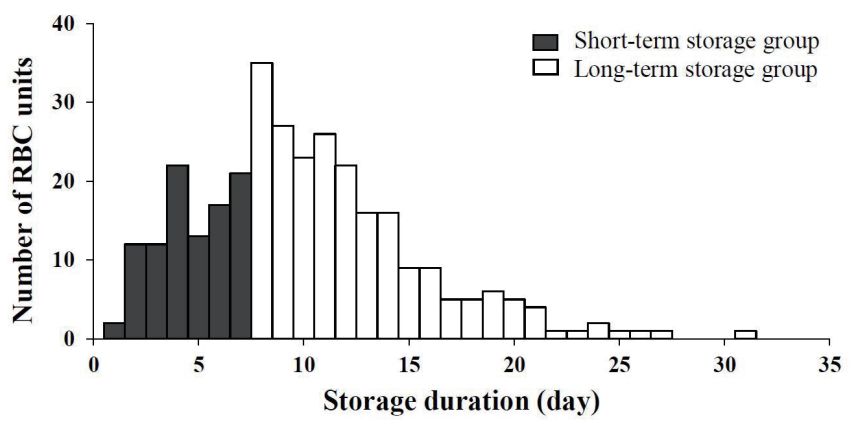

Figure 1. Duration of red blood cell (RBC) storage by study group. The mean storage period of red blood cells was $10.01 \pm 5.13$ days, ranging from 1 day to a maximum of 32 days. The means of the short-term and long-term storage groups were $4.69 \pm 1.75$ and 12.45 \pm 4.25 days, respectively.

간주하였다.

\section{결과}

적혈구 제제 저장 기간은 평균 $10.01 \pm 5.13$ 일로, 최소 1 일부터 최 대 32 일이었다. 단기 저장군의 평균은 $4.69 \pm 1.75$ 일, 장기 저장군의 평균은 $12.45 \pm 4.25$ 일이었다(Figure 1).

연구 기간 동안 1,748 명의 신생아 중 315 명(18\%), 383명의 VLBWI 중 222명(58\%), 136명의 초극소 저체중 출생아(extremely low birth weight infants, ELBWI) 중 99명(73\%)이 1회 이상의 적혈구 수혈을 받았다. 315 명의 환자는 입원 기간 중 평균 $3.51 \pm 3.33$ 회의 적혈구 수혈을 받았다. 이 중 190 명은 2 회 이상 수혈받았고 수혈 간격은 평 균 $11.51 \pm 2.74$ 일이었다.

대상 환자 289 명의 평균 재태 연령은 $29.60 \pm 3.52$ 주였으며, 평균 출생체중은 $1,347.84 \pm 630.79 \mathrm{~g}$ 이었다. 자연분만이 74 명 $(25.6 \%)$, 다 태아가 71 명 $(24.6 \%$ )이었으며 1분, 5 분 아프가 점수는 각각 5점, 8 점, 입원 시 혈색소 수치는 $14.46 \pm 2.14 \mathrm{~g} / \mathrm{dL}$ 이었다. 단기 저장군과 장기 저장군의 재태 연령, 출생체중, 분만방법, 성별, 다태아 유무, 쌍생아 간 수혈증후군, 아프가 점수, 입원 시 혈색소 수치, 입원 중 총 적혈 구 수혈 횟수의 유의한 차이는 없었다(Table 1).

첫 수혈 시 평균 연령은 $13.69 \pm 12.31$ 일이었으며 평균 수혈 양 은 $12.25 \pm 2.66 \mathrm{cc} / \mathrm{kg}$ 이었다. 수혈 당시에 111 명(38.7\%)에서 침습 적 인공호흡기를 사용하고 있었으며 단기 저장군(28.4\%)에 비해 장 기 저장군( $42.8 \%)$ 에서 유의하게 높았다 $(P=0.023)$. 그 외 두 군 간 임상적 특징의 유의한 차이는 없었다(Table 2). 수혈 전후 2 주 이내 동반된 질환은 뇌실내출혈 66명 (23\%), 혈액 질환 4명(1.4\%), Bell's staging criteria IIa 이상의 괴사성 장염 8명(2.8\%), 위장관 출혈 3명 (1.0\%), 패혈증 10 명(3.5\%)으로 두 군 간의 차이는 없었다(Table 2). 혈액 질환으로는 급성골수성백혈병 2 건, 일과성 골수형성이상증
Table 1. Characteristics of the Subjects

\begin{tabular}{|c|c|c|c|}
\hline Characteristic & $\begin{array}{l}\text { Short-term } \\
\text { storage group } \\
\quad(\mathbf{n}=\mathbf{8 8})\end{array}$ & $\begin{array}{l}\text { Long-term } \\
\text { storage group } \\
\quad(n=201)\end{array}$ & $\begin{array}{c}P \text { - } \\
\text { value }\end{array}$ \\
\hline \multicolumn{4}{|l|}{ Gestational age } \\
\hline Mean \pm SD (wk) & $29.69 \pm 3.42$ & $29.55 \pm 3.57$ & 0.641 \\
\hline$<32 \mathrm{wk}$ & $71(80.7)$ & $160(79.6)$ & 0.833 \\
\hline$\geq 32 \mathrm{wk}$ & $17(19.3)$ & $41(20.4)$ & \\
\hline \multicolumn{4}{|l|}{ Birth weight } \\
\hline Mean \pm SD (g) & $1,350.03 \pm 668.70$ & $1,346.88 \pm 615.18$ & 0.797 \\
\hline$<1,500 \mathrm{~g}$ & $64(72.7)$ & $147(73.1)$ & 0.943 \\
\hline$\geq 1,500 \mathrm{~g}$ & $24(27.3)$ & $54(26.9)$ & \\
\hline \multicolumn{4}{|l|}{ Type of delivery } \\
\hline NSVD & $16(18.2)$ & $58(28.9)$ & 0.056 \\
\hline C-sec & $72(81.8)$ & $143(71.1)$ & \\
\hline \multicolumn{4}{|l|}{ Sex } \\
\hline Male & $42(47.7)$ & $110(54.7)$ & 0.273 \\
\hline Female & $46(52.3)$ & $91(45.3)$ & \\
\hline \multicolumn{4}{|l|}{ Multiple birth } \\
\hline Twin or triplet & $20(22.7)$ & $51(25.4)$ & 0.631 \\
\hline Singleton & $68(77.3)$ & $150(74.6)$ & \\
\hline TTTS & & & 0.285 \\
\hline Donor twin & $3(3.4)$ & $4(1.9)$ & \\
\hline Recipient twin & $1(1.1)$ & 0 & \\
\hline \multicolumn{4}{|l|}{ Apgar score } \\
\hline $1 \mathrm{~min}$ & $5(4-7)$ & $5(4-6)$ & 0.441 \\
\hline $5 \mathrm{~min}$ & $8(8-9)$ & $8(8-9)$ & 0.250 \\
\hline Initial hemoglobin (g/dL) & $14.79 \pm 2.06$ & $14.32 \pm 2.16$ & 0.156 \\
\hline Total no. of RBC transfusion* & $3.78 \pm 3.83$ & $3.39 \pm 3.09$ & 0.646 \\
\hline
\end{tabular}

Values are expressed as mean \pm standard deviation, number (\%), or median (interquartile range).

*During admission.

Abbreviations: NSVD, normal spontaneous vaginal delivery; C-sec, caesarean section; TTTS, twin-to-twin transfusion syndrome; RBC, red blood cell.

후군 1 건, 용혈 빈혈 1 건이 있었다. 수혈 전후 2 주 이내 수술을 시행 한 환자는 48 명 (16.6\%)이었으며 두 군 간의 유의한 차이는 없었다. 수술로는 동맥관결찰술이 36건으로 가장 많았고 소장 무신경절증 (aganglionosis), 항문막힘증, 선천거대결장, 기관식도루, 신생아 괴 사성 장염 등의 위장관계 수술이 9건이었고 천미부기형종 제거술, 기관지 천공 재건술, 고관절 화농관절염 절개배농술이 각각 1 건 있 었다. 수혈 후 5-9일 째 혈색소를 확인하기 전에 $1 \mathrm{cc}$ 이상 추가 채혈 을 했거나 추가 수혈이 있었던 경우는 각각 평균 $1.37 \pm 1.65$ 회, 1.30 \pm 0.67 회였으며 두 군 간의 차이는 없었다(Table 2).

수혈 전 혈색소 수치는 평균 $10.24 \pm 1.99 \mathrm{~g} / \mathrm{dL}$ 이었으며 두 군 간의 유의한 차이가 없었다. 수혈 전후 혈색소 수치의 변화는 단기 저장 군 $1.25 \pm 2.20 \mathrm{~g} / \mathrm{dL}$, 장기 저장군 $1.49 \pm 1.83 \mathrm{~g} / \mathrm{dL}$ 로 두 군 간의 유의 
한 차이는 없었다 $(P=0.537)$ (Table 3, Figure 2). 적혈구 제제의 저장 일수에 따른 수혈 전후 혈색소 수치의 변화를 분석해 보았을 때에도 회귀분석 유의 확률 0.152 로 유의한 관련은 없었다(Figure 3). 연구 대상을 VLBWI 211명으로 제한하여 단기 저장군과 장기 저장군 간 의 혈색소 교정 효과를 비교해 보았다. 단기 저장군 $0.81 \pm 2.03 \mathrm{~g} / \mathrm{dL}$

Table 2. Clinical Characteristics of the Short-Term and LongTerm Storage Groups

\begin{tabular}{|c|c|c|c|}
\hline Characteristic & $\begin{array}{l}\text { Short-term } \\
\text { storage group } \\
\quad(n=88)\end{array}$ & $\begin{array}{l}\text { Long-term } \\
\text { storage group } \\
\quad(\mathbf{n}=\mathbf{2 0 1})\end{array}$ & $\begin{array}{c}P_{-} \\
\text {value }\end{array}$ \\
\hline \multicolumn{4}{|l|}{ Condition at transfusion } \\
\hline Age (postnatal d) & $14.05 \pm 13.71$ & $13.54 \pm 11.68$ & 0.708 \\
\hline Weight (kg) & $1.46 \pm 0.72$ & $1.44 \pm 0.68$ & 0.943 \\
\hline Transfusion volume (cc/kg) & $12.03 \pm 2.44$ & $12.34 \pm 2.75$ & 0.347 \\
\hline $\begin{array}{l}\text { Enteral feeding volume } \\
\quad(\mathrm{cc} / \mathrm{kg} / \mathrm{d})\end{array}$ & $46.62 \pm 57.21$ & $47.02 \pm 58.79$ & 0.620 \\
\hline Parenteral nutrition & $70(79.5)$ & $158(78.6)$ & 0.857 \\
\hline Use of invasive ventilator & $25(28.4)$ & $86(42.8)$ & 0.023 \\
\hline $\mathrm{CRP}(\mathrm{mg} / \mathrm{dL})$ & $0.87 \pm 2.26$ & $1.00 \pm 2.20$ & 0.475 \\
\hline \multicolumn{4}{|l|}{ Accompanying disease* } \\
\hline IVH & & & 0.248 \\
\hline Grade 1 or 2 & $9(10.2)$ & $24(11.9)$ & \\
\hline Grade 3 or 4 & $6(6.8)$ & $27(13.4)$ & \\
\hline Other disease & & & 0.253 \\
\hline Hematologic disease & $1(1.1)$ & $3(1.5)$ & \\
\hline $\mathrm{NEC}^{\dagger}$ & $2(2.3)$ & $6(3.0)$ & \\
\hline GI bleeding & $2(2.3)$ & $1(0.5)$ & \\
\hline Sepsis & $1(1.1)$ & $9(4.5)$ & \\
\hline Operation & $11(12.5)$ & $37(18.4)$ & 0.214 \\
\hline No. of blood sampling ${ }^{\dagger}$ & $1.34 \pm 1.43$ & $1.39 \pm 1.75$ & 0.677 \\
\hline No. of additional transfusion ${ }^{*}$ & $1.26 \pm 0.58$ & $1.31 \pm 0.70$ & 0.796 \\
\hline
\end{tabular}

Values are expressed as mean \pm standard deviation or number (\%), *Within 2 weeks before and after the first transfusion; ${ }^{\dagger}$ Bell's staging criteria IIa or above; ${ }^{*}$ Within 5 to 9 days after the first transfusion. Abbreviations: CRP, C-reactive protein; IVH, intraventricular hemorrhage; NEC, necrotizing enterocolitis; GI, gastrointestinal.
장기 저장군 $1.34 \pm 1.84 \mathrm{~g} / \mathrm{dL}$ 로 두 군 간의 유의한 차이는 없었다 $(P=$ 0.166) (Table 3).

적혈구 저장 기간 외에 수혈 후 혈색소 수치 교정 효과에 영향을 줄 수 있는 인자를 확인해 보았다. 일변량 분석에서는 출생체중이 $1,500 \mathrm{~g}$ 이상인 경우, 수혈 당시의 출생 후 나이와 체중, 수혈 양, 장관 영양 진행 정도, 침습적 인공호흡기 사용, 수혈 전 혈색소 수치, 수술 여부, 추가 채혈 횟수가 연관이 있었다(Table 4). 다변량 분석에서는 출생체중이 $1,500 \mathrm{~g}$ 이상인 경우, 수혈 당시 체중이 클수록, 수혈 양 이 많을수록 많이 교정되었으며 수혈 전후로 수술을 하였던 경우, 추 가 채혈 횟수가 많을수록, 수혈 전 혈색소가 높을수록 적게 교정되었 다. 일부 변수는 일변량 분석에서는 유의했지만, 다변량 분석에서는 수혈 후 혈색소 교정 효과와 관련되지 않는 것으로 확인되었다.

\section{고찰}

일반적으로 신생아중환자실에서 적혈구 수혈을 결정할 때는 혈

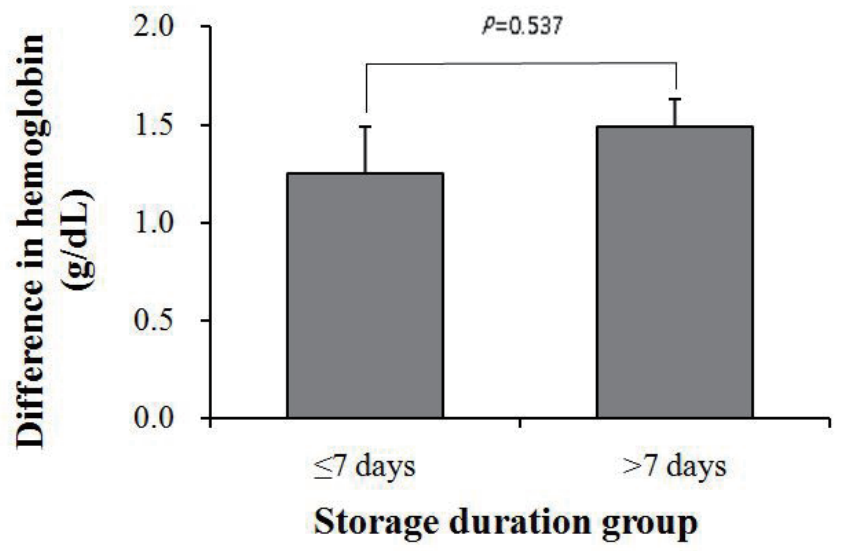

Figure 2. Comparison of differences in hemoglobin levels between the short-term and long-term storage groups. There was no significant difference between changes in hemoglobin levels before and after transfusion. It was $1.25 \pm 2.20 \mathrm{~g} / \mathrm{dL}$ in the shortterm storage group and $1.49 \pm 1.83 \mathrm{~g} / \mathrm{dL}$ in the long-term storage group $(P=0.537)$.

Table 3. Changes in Hemoglobin Levels before and after the Transfusion

\begin{tabular}{|c|c|c|c|c|c|c|}
\hline \multirow{2}{*}{$\begin{array}{l}\text { Hemoglobin level } \\
(\mathrm{mg} / \mathrm{dL})\end{array}$} & \multicolumn{3}{|c|}{ Total } & \multicolumn{3}{|c|}{ VLBWI } \\
\hline & $\begin{array}{l}\text { Short-term storage } \\
\text { group }(n=88)\end{array}$ & $\begin{array}{l}\text { Long-term storage } \\
\text { group }(n=201)\end{array}$ & $P$-value & $\begin{array}{l}\text { Short-term storage } \\
\text { group }(n=64)\end{array}$ & $\begin{array}{c}\text { Long-term storage } \\
\text { group }(n=147)\end{array}$ & $P$-value \\
\hline Before transfusion* & $10.54 \pm 2.30$ & $10.11 \pm 1.83$ & 0.281 & $10.50 \pm 2.13$ & $9.97 \pm 1.64$ & 0.175 \\
\hline After transfusion $^{\dagger}$ & $11.79 \pm 1.92$ & $11.61 \pm 1.87$ & 0.738 & $11.31 \pm 1.40$ & $11.31 \pm 1.69$ & 0.944 \\
\hline Difference & $1.25 \pm 2.20$ & $1.49 \pm 1.83$ & 0.537 & $0.81 \pm 2.03$ & $1.34 \pm 1.84$ & 0.166 \\
\hline
\end{tabular}

Values are expressed as mean \pm standard deviation.

*Within 2 days before the first transfusion; ${ }^{\dagger} 5$ to 9 days after the first transfusion.

Abbreviation: VLBWI, very low birth weight infant. 


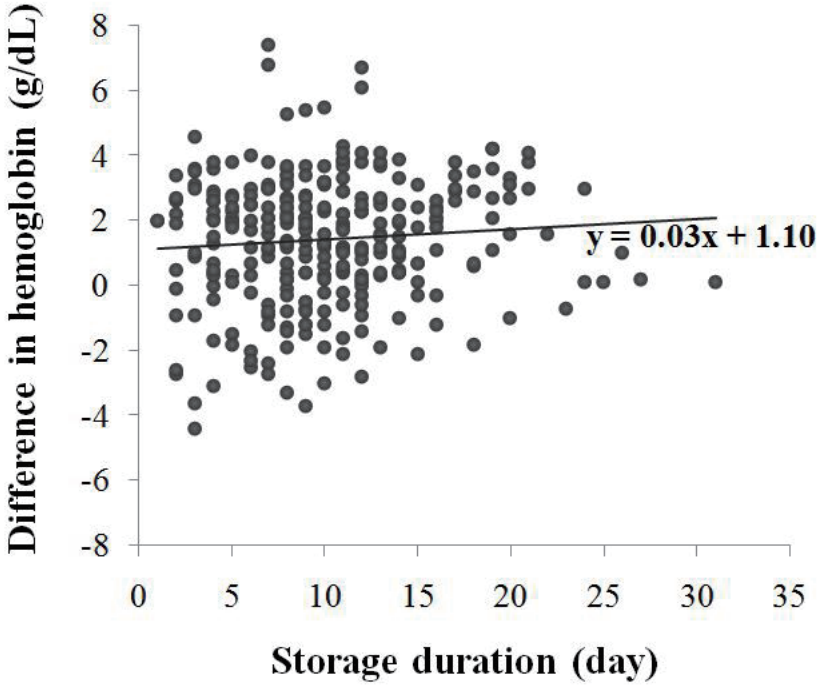

Figure 3. Red blood cell storage duration versus the difference in hemoglobin levels in the total study group. There was no statistically significant correlation between the number of days of storage of red blood cells and the change in hemoglobin levels before and after blood transfusion $(P=0.152)$.
색소 기준 뿐만 아니라 산소화 개선이 필요한 심폐기능 여부도 고려 한다 ${ }^{5,18)}$. 그러나 입원 후 첫 수혈 시기인 급성기에는 심폐기능이 불 안정한 시기이고 신생아 적혈구 수혈지침들도 상대적으로 높은 혈 색소 기준을 제시하고 있어 빈번한 수혈이 이 시기에 이루어진다,19 ${ }^{21)}$. 이때 만일 저장 기간이 긴 적혈구 수혈 시 혈색소 교정 효과가 낮 다면 반복 수혈을 하게 되어 공여자 노출 기회가 증가할 수 있다.

본 연구에서 저자들은 7일을 기준으로 단기와 장기 저장 적혈구 수혈 후 혈색소 교정 효과를 비교하였고 의미 있는 차이가 없음을 확 인하였다. 이에 적혈구 저장 기간 외에 적혈구 교정 효과에 영향을 줄 수 있는 요인을 분석해 보았다. 출생체중 $1,500 \mathrm{~g}$ 이상, 수혈 시 체 중이 클수록, 1 회 수혈 양이 많을수록 수혈 후 혈색소 교정 효과가 큰 반면에 수혈 전 혈색소가 높을수록, 수혈 전후 2주 이내 수술을 한 경 우, 추가 채혈 횟수가 많을수록 수혈 후 혈색소 교정 효과가 작음을 확인하였다.

연구 기간 동안 전체 신생아중환자실 입원 환자의 1 회 이상 수혈 빈도는 $18 \%, \mathrm{VLBWI}$ 에서는 $58 \%, \mathrm{ELBWI}$ 에서는 $73 \%$ 로 다른 연구들 에서 보고한 각각 $17 \%, 55 \%, 80 \%$ 와 비슷한 정도였다 ${ }^{5,18-20,22)} .2$ 회 이 상 수혈받은 환자 중 수혈 사이의 간격은 평균 $11.51 \pm 2.74$ 일로 분할 적혈구 사용 시 충분히 공여자 노출을 줄일 수 있는 정도였다. 전체 수혈 환자의 입원 기간 중 평균 수혈 횟수는 $3.51 \pm 3.33$ 회였고 단기 저장군과 장기 저장군의 총 수혈 횟수 차이가 없었는데 첫 수혈에 한 해 저장 기간을 분류하였고 두 번째 수혈부터는 적혈구 제제의 저장

Table 4. Univariate and Multivariate Linear Regression Analyses of Hemoglobin Level Changes

\begin{tabular}{|c|c|c|c|c|c|c|}
\hline \multirow{2}{*}{ Variable } & \multicolumn{3}{|c|}{ Univariate } & \multicolumn{3}{|c|}{ Multivariate } \\
\hline & Beta & 95\% CI & $P$-value & Beta & $95 \% \mathrm{CI}$ & $P$-value \\
\hline Storage duration $(>7 \mathrm{~d})$ & 0.06 & -0.25 to 0.73 & 0.336 & & & \\
\hline GA ( $\geq 32$ wk) & 0.11 & -0.01 to 1.12 & 0.052 & & & \\
\hline Birth weight ( $\geq 1,500 \mathrm{~g})$ & 0.20 & 0.39 to 1.39 & 0.000 & 0.15 & 0.08 to 1.22 & 0.025 \\
\hline Initial $\mathrm{Hb}(\mathrm{mg} / \mathrm{dL})$ & 0.00 & -0.10 to 0.11 & 0.950 & & & \\
\hline Age (postnatal d)* & 0.46 & 0.06 to 0.09 & 0.000 & & & \\
\hline Weight $(\mathrm{kg})^{*}$ & 0.32 & 0.00 to 0.00 & 0.000 & 0.17 & 0.10 to 0.86 & 0.012 \\
\hline Transfusion volume (cc/kg) & 0.32 & 0.15 to 0.32 & 0.000 & 0.18 & 0.06 to 0.20 & 0.000 \\
\hline Enteral feeding $(\mathrm{cc} / \mathrm{kg})^{*}$ & 0.40 & 0.01 to 0.02 & 0.000 & & & \\
\hline Use of invasive ventilator* & -0.22 & -1.31 to -0.41 & 0.000 & & & \\
\hline $\mathrm{CRP}(\mathrm{mg} / \mathrm{dL})^{\dagger}$ & -0.01 & -0.11 to 0.09 & 0.829 & & & \\
\hline $\mathrm{Hb}(\mathrm{mg} / \mathrm{dL})^{\dagger}$ & -0.54 & -0.63 to -0.44 & 0.000 & -0.43 & -0.52 to -0.32 & 0.000 \\
\hline IVH ( 1 or 2 vs. negative $)^{\ddagger}$ & -0.07 & -1.17 to 0.27 & 0.219 & & & \\
\hline IVH $(3 \text { or } 4 \text { vs. negative })^{*}$ & -0.01 & -0.75 to 0.68 & 0.925 & & & \\
\hline Operation $^{\ddagger}$ & -0.16 & -1.45 to -0.25 & 0.006 & -0.11 & -1.06 to -0.13 & 0.012 \\
\hline No. of blood sampling ${ }^{\S}$ & -0.34 & -0.53 to -0.27 & 0.000 & -0.25 & -0.40 to -0.18 & 0.000 \\
\hline No. of additional transfusion $\$$ & -0.07 & -0.54 to 0.14 & 0.244 & & & \\
\hline
\end{tabular}

*At transfusion; ${ }^{\dagger}$ Within 2 days before transfusion; ${ }^{\dagger}$ Within 2 weeks before and after transfusion; ${ }^{5}$ Within 5 to 9 days after transfusion. Abbreviations: Beta, unstandardized regression efficient; CI, confidence interval; GA, gestational age; Hb, hemoglobin; CRP, C-reactive protein; $\mathrm{IVH}$, intraventricular hemorrhage. 
기간을 고려하지 않았기 때문에 이는 저장 기간에 따른 영향으로 볼 수 없었다.

첫 수혈 시 평균 연령은 $13.69 \pm 12.31$ 일이었는데 이는 다른 연구 들의 VLBWI가 생후 첫 2주 이내 수혈한다는 결과와 비슷하였다 $5,15,19,23,24)$. 첫 수혈 당시 장기 저장군에서 침습적 인공호흡기 사용 빈 도가 $42.8 \%$ 로 유의하게 높았는데 이는 심폐기능이 불안정한 상태에 서 수혈 양을 늘리게 되어 장기 저장군의 수혈 후 혈색소 교정 효과 를 호전시키는 교란 요인이 되었을 수 있다. 그러나 이 환자들의 추 가 채혈 횟수도 많았을 것을 고려한다면 그 효과는 상쇄될 수 있을 것이다.

수혈 전 혈색소 수치는 평균 $10.24 \pm 1.99 \mathrm{~g} / \mathrm{dL}$ 이었는데 생후 첫 수 혈을 대상으로 했기 때문에 심폐기능이 불안정한 시기, 혈액가스검 사가 잦은 시기, 뇌실내출혈 고위험 시기, 수술을 주로 했던 시기와 맞물려 있어 다소 높은 혈색소 수치에서 수혈 결정을 한 것으로 추측 된다. 수혈 전후 혈색소 수치의 변화는 전체 평균 $1.42 \pm 1.95 \mathrm{~g} / \mathrm{dL}$ 이 며 두 군 간의 차이가 없었다. 이는 VLBWI 또는 32주 미만 미숙아에 서 시행 된 수혈 연구에서 평균 혈색소 상승치가 $2.3 \pm 2.1 \mathrm{~g} / \mathrm{dL}$ 에 비 해 낮았다. 그러나 이는 수혈 전후 24 시간 이내의 혈색소를 검사한 결과이므로 직접 비교할 수는 없다 ${ }^{19)}$. 본 연구에서는 수혈 후 5-9일 째 혈색소 수치와 수혈 전 이틀 이내 혈색소 수치를 비교했으므로 그 차이가 다소 작을 수 있겠다. Mangel 등 ${ }^{13)}$ 은 분할적혈구 사용으로 인해 저장 기간이 긴 적혈구 제제의 수혈 빈도가 증가함에 따라 장기 저장 적혈구의 혈색소 상승효과를 연구하였다. 미숙아에게 $7 \mathrm{cc} / \mathrm{kg}$ 의 수혈을 한 후 수혈 12시간 전후의 환자 혈색소 차이를 조사하였 다. 적혈구 저장 기간을 10 일 미만 $(n=86), 10-20$ 일 $(n=105), 21-35$ 일 $(n=44)$ 세 군으로 나누어 비교했을 때 평균 적혈구 용적률의 교정 효 과는 세 군 간의 차이가 없었다.

미숙아에게 적용되는 수혈 적응증은 명확하지 않다. 특히 첫 수혈 시는 불안정한 임상 상황과 잦은 채혈, 뇌실내출혈과 수술 등 실혈이 발생하는 시기이기 때문에 흔히 2회 이상의 수혈이 요구된다 ${ }^{8,19)}$. 이 시기는 불안정한 시기이며 다소 높은 혈색소 수치에서도 수혈이 결 정되기 때문에 반복 수혈을 하더라도 분할적혈구를 사용하면 공여 자 노출 기회를 줄일 수 있다 ${ }^{20)}$. 그렇다고 모든 수혈 상황에서 분할 적혈구를 제공한다면 반복 수혈이 필요치 않을 때는 폐기되는 혈액 과 공여자 노출 기회 감소의 장점 없이 비용만을 상승시키는 결과를 초래할 것이다. 따라서 반복 수혈의 위험요인을 파악할 수 있다면 신선혈액을 분할적혈구로 보관하여 혈액 폐기량과 공여자 노출 기 회를 감소시킬 수 있을 것이다.

앞선 연구에서 작은 체중과 어린 재태 연령, 남아, 동반 질환(패혈 증, 동맥관개존증, 기관지폐이형성증, 파종성혈관내응고)이 있을 때 수혈 요구가 증가 된다고 보고하였다 ${ }^{19,22,25)}$. 재태 연령 30주 미만 미 숙아의 생후 2주 이후 반복 수혈에 대한 양성 예측률이 0.87 이라는 연구도 있다 ${ }^{26)}$. 저자들은 본 연구를 통해 수혈 전 혈색소가 높을수
록, 수혈 2주 이내 수술을 한 경우, 추가 채혈 횟수가 많았던 경우 혈 색소 교정 효과가 낮음을 확인하였다. 수혈 전 혈색소가 높은 환자 에서 혈색소 교정 효과가 낮았는데 환자의 상황이 불안정했기 때문 에 더 높은 혈색소 수치에도 불구하고 수혈 결정을 했을 것이고 이러 한 불안정한 상황으로 인해 혈색소 교정 효과가 낮았을 것으로 생각 된다. 따라서 임상적으로 불안정한 경우, 수술 시행 전후, 추가 채혈 횟수가 많을 것이 예상되는 경우 반복 수혈의 위험요인으로 생각하 여 분할적혈구를 사용한다면 공여자 노출 기회를 줄일 수 있을 것이 다 ${ }^{21)}$.

본 연구의 제한점은 단일 의료기관에서 시행한 비교 분석이며 후 향적 연구라는 한계가 있다. 또한, 입원 기간 중 첫 수혈에 대해서만 조사했기 때문에 급성기의 불안정한 상황으로 인해 혈색소 교정 효 과에 영향을 미치는 변수가 많았을 것으로 생각된다. 한 환자가 2회 이상 수혈하게 되면 단기 및 장기 저장 적혈구에 모두 노출되었으므 로 저장 기간에 따라 입원 기간 중 총 수혈 횟수에 차이가 생기는지 는 확인할 수 없었다. 수혈 후 5-9일 이내 단기간의 혈색소 교정 효 과는 비교하였으나 잦은 채혈, 반복 수혈 등의 다른 변수 개입이 많 아 장기간의 혈색소 교정 효과는 비교하지 못하였다.

이 연구를 통해 7일 기준으로 단기 또는 장기 저장 적혈구 수혈 후 혈색소 교정 효과에 의미 있는 차이가 없음을 확인하였다. VLBWI의 첫 수혈 시 임상적으로 불안정한 경우, 수술 시행 전후, 추가 채혈 횟 수가 많을 것으로 예상되는 경우에는 반복 수혈이 있을 것을 감안하 여 첫 수혈 시 분할적혈구를 사용한다면 공여자 노출 기회와 폐기 혈 액 감소에 효과적일 것이다 ${ }^{21)}$.

\section{REFERENCES}

1. Quinn K, Quinn M, Moreno C, Soundar E, Teruya J, Hui SK. Neonatal transfusion models to determine the impact of using fresh red blood cells on inventory and exposure. Blood Transfus 2015;13:595-9.

2. Lee SH, Yoon J, Park Y, Lee SK, Kim HC, Shim WS. The use of quadruple blood bags transfusion of low birth weight neonates. J Korean Pediatr Soc 1999;42:1122-9.

3. Bell EF, Strauss RG, Widness JA, Mahoney LT, Mock DM, Seward VJ, et al. Randomized trial of liberal versus restrictive guidelines for red blood cell transfusion in preterm infants. Pediatrics 2005;115:1685-91.

4. Kim HM. Advances in neonatal care and outcome of low birth weight infants. J Korean Pediatr Soc 1996;39:762-72.

5. Kim SS. Optimal hemoglobin level in preterm infants. Neonatal Med 2014;21:92-8.

6. Fernandes da Cunha DH, Nunes Dos Santos AM, Kopelman BI, Areco KN, Guinsburg R, de Araujo Peres C, et al. Transfusions of 
CPDA-1 red blood cells stored for up to 28 days decrease donor exposures in very low-birth-weight premature infants. Transfus Med 2005;15:467-73.

7. Kasat K, Hendricks-Munoz KD, Mally PV. Neonatal red blood cell transfusions: searching for better guidelines. Blood Transfus 2011;9:86-94.

8. Whyte RK, Jefferies AL; Canadian Paediatric Society, Fetus and Newborn Committee. Red blood cell transfusion in newborn infants. Paediatr Child Health 2014;19:213-22.

9. Tinmouth A, Fergusson D, Yee IC, Hebert PC; ABLE Investigators; Canadian Critical Care Trials Group. Clinical consequences of red cell storage in the critically ill. Transfusion 2006; 46:2014-27.

10. Hogman CF, Meryman HT. Storage parameters affecting red blood cell survival and function after transfusion. Transfus Med Rev 1999;13:275-96.

11. Hess JR. Red cell storage. J Proteomics 2010;73:368-73.

12. Lion N, Crettaz D, Rubin O, Tissot JD. Stored red blood cells: a changing universe waiting for its map(s). J Proteomics 2010;73: 374-85.

13. Mangel J, Goldman M, Garcia C, Spurll G. Reduction of donor exposures in premature infants by the use of designated adenine-saline preserved split red blood cell packs. J Perinatol 2001;21:363-7.

14. Fergusson DA, Hebert P, Hogan DL, LeBel L, Rouvinez-Bouali $\mathrm{N}$, Smyth JA, et al. Effect of fresh red blood cell transfusions on clinical outcomes in premature, very low-birth-weight infants: the ARIPI randomized trial. JAMA 2012;308:1443-51.

15. Lee DA, Slagle TA, Jackson TM, Evans CS. Reducing blood donor exposures in low birth weight infants by the use of older, unwashed packed red blood cells. J Pediatr 1995;126:280-6.

16. BISS. Blood Information Sharing System [Internet]. Wonju: KOREAN Redcross Blood Services; 2018 [cited 2018 Nov 21]. Available from: http://biss.bloodinfo.net.
17. The Korean Society of Neonatology. Indications of transfusion in manual of neonatal care. 3rd ed. Seoul: The Korean Society of Neonatology, 2014.

18. Nortfolk D. Neonatal transfusion. In: Norfolk D, editor. Handbook for transfusion medicine. 5th ed. Norwich: Joint United Kingdom (UK) Blood Transfusion and Tissue Transplantation Services Professional Advisory Committee, 2013 [cited 2018 Nov 21]. Available from: https://www.transfusionguidelines.org/ transfusion-handbook/10-effective-transfusion-in-paediatricpractice/10-2-neonatal-transfusion

19. Shanmugha Priya RA, Krishnamoorthy R, Panicker VK, Ninan B. Transfusion support in preterm neonates $<1500 \mathrm{~g}$ and/or $<32$ weeks in a tertiary care center: a descriptive study. Asian J Transfus Sci 2018;12:34-41.

20. Fasano RM, Luban N. Blood component therapy for the neonate. In: Martin RJ, Fanaroff AA, Walsh MC. editors. Fanaroff and Martin's neonatal-perinatal medicine. 10th ed. Cleveland: Elsevier, 2015:1344-61.

21. New York State Department of Health. Guidelines for transfusion therapy of infants from birth to four months of age. 2nd ed. New York: New York State Council on Human Blood and Transfusion services, 2004.

22. Said Conti V, Azzopardi E, Parascandalo R, Soler P, Attard Montalto S. Overview of the blood transfusion policy in preterms on the neonatal intensive care unit. Malta Med J 2013;25:46-50.

23. Jeon GW, Sin JB. Risk factors of transfusion in anemia of very low birth weight infants. Yonsei Med J 2013;54:366-73.

24. Alan S, Arsan S. Prevention of the anaemia of prematurity. Int J Pediatr Adolesc Med 2015;2:99-106.

25. Freitas BA, Franceschini Sdo C. Factors associated with packed red blood cell transfusions in premature infants in an intensive care unit. Rev Bras Ter Intensiva 2012;24:224-9.

26. Liu EA, Mannino FL, Lane TA. Prospective, randomized trial of the safety and efficacy of a limited donor exposure transfusion program for premature neonates. J Pediatr 1994;125:92-6. 
Appendix. 일반적 적혈구 수혈 적응증

1. Hematocrit <21\% (혈색소 $<7 \mathrm{~g} / \mathrm{dL}$ )인 경우

1) 증상이 없더라도 망상적혈구 수가 $\langle 100,000 / \mu \mathrm{L}(2 \%)$ 인 경우

2. Hematocrit <31\%인 경우

1) $\mathrm{FiO}_{2}<36 \%$ 의 산소 투여가 필요한 경우

2) 평균기도압 $<6 \mathrm{cmH}_{2} \mathrm{O}$ 로 경비적 양압환기나 기계적 환기요법이 필요한 경우

3) Methylxanthine제제를 투여함에도 불구하고 유의한 무호흡이 있는 경우

4) 24 시간 이상 지속적으로 심박수>180회/분, 또는 호흡수 > 80 회/분인 경우

5) $100 \mathrm{kcal} / \mathrm{kg} / \mathrm{d}$ 의 영양공급에도 불구하고 체중증가가 4 일 연속 $<10 \mathrm{~g} / \mathrm{d}$ 인 경우

6) 수술을 하게 되는 경우

3. Hematocrit $<36 \%$ 인 경우

1) $\mathrm{FIO}_{2}>35 \%$ 의 산소 투여가 필요한 경우

2) 평균기도압 6-8 $\mathrm{cmH}_{2} \mathrm{O}$ 의 경비적 양압환기 또는 기계적 환기요법이 필요한 경우

4. 단순히 채혈로 소실된 혈액을 보충할 목적으로는 수혈하지 않는다. 